\section{ANALISIS BAURAN PEMASARAN DALAM KAITANNYA DENGAN KEPUASAN KONSUMEN DAN PENGARUHNYA TERHADAP KEPUTUSAN PEMBELIAN \\ (Studi Kasus Penjualan Mebel Pada PT Multi Manunggal)}

\author{
Sujana dan Mardy Setiawan \\ Program Studi Manajemen, Sekolah Tinggi Ilmu Ekonomi Kesatuan \\ Bogor, Indonesia \\ Email : lemlit@stiekesatuan.ac.id
}

Marketing mix, Customers' satisfaction

007

Submitted: JANUARI 2016

Accepted: FEBRUARI 2016

A Company's main objective when running a business is to achieve the highest possible profit and sales and to develop markets all circles by performing campaigns and provide attractive offers to the consumer that the products sold by the company attract attention from consumers and companies acquire more consumers. If the company able to deliver what consumers want and making consumers satisfied with products that are produced by the company, then consumers will always buy the products that are sold by the company. The purpose of this research is to know how to influence the marketing mix to the satisfaction of the customer, to find out how the marketing mix of influences purchasing decisions, and to find out how the influence of customer satisfaction on purchasing decisions. As for the marketing mix variables, consumer satisfaction, and purchasing decisions will be identified and quantified the extent of the influence of these variables. The evaluation results in this study show that purchasing decisions on PT Multi Manunggal furniture can be influenced by the marketing mix and customer satisfaction by way of perfecting all activities such as good skills, knowledge, and expertise as well as discipline which are enforced programmatically by the company, to achieve optimal results. As for the marketing focused by PT Multi Manunggal, marketing mix of quality will be effecting positively the purchasing decisions and consumer satisfaction on an ongoing basis.

Keywords : marketing mix, customer satisfaction, and the decision of purchasing

\title{
PENDAHULUAN
}

Pemasaran yang baik bukan sebuah kebetulan, melainkan hasil dari perencanaan dan pelaksanaan yang cermat. Di dalam pemasaran ada bagian yang sangat menarik untuk ditelusuri, yaitu bauran pemasaran. Bauran pemasaran adalah strategi produk, promosi, penetapan lokasi/saluran distribusi dan penetuan harga yang bersifat unik, serta dirancang untuk menghasilkan pertukaran yang saling menguntungkan dengan pasar yang dituju. Bauran pemasaran dapat mempengaruhi kepuasan konsumen dan keputusan pembelian.

Komunikasi pemasaran terdiri dari beberapa elemen yang dipadukan, sehingga dapat terwujud dalam bauran komunikasi pemasaran terpadu, yaitu bauran pemasaran (marketing mix), lalu bauran promosi (promotion mix) yang sebenarnya adalah bagian dari marketing mix, namun kini lebih spesifik. Strategi komunikasi pemasaran terdiri dari strategi segmenting, strategi targeting, strategi pricing, dan strategi positioning. Dalam marketing mix perusahaan terdapat unsur-unsur yang menjadi dasar pertimbangan pengambilan keputusan dalam pembuatan strategi komunikasi pemasaran, yaitu 4P yang terdiri dari product, place, price, dan promotion. Menciptakan hubungan yang kuat dan erat dengan konsumen adalah mimpi semua pemasar dan hal ini sering menjadi kunci keberhasilan pemasaran jangka panjang.

\section{JIMKES}

Jurnal Ilmiah Manajemen Kesatuan Vol. 4 No.1, 2016 pg. $007-014$ ISSN $2337-7860$ 
Marketing mix, Customers' satisfaction

$\underline{008}$

Strategi pemasaran untuk menciptakan kepuasan konsumen dan keputusan pembelian dipengaruhi oleh barang atau jasa yang dibutuhkan konsumen, harga barang atau jasa, upaya mendistribusikan barang atau jasa dari produsen kepada konsumen, dan kegiatan memperkenalkan kepada konsumen (promosi). Jelasnya bahwa kegiatan memasarkan suatu produk dipengaruhi oleh interaksi dari keempat hal tersebut di atas, dalam buku teks bahasa inggris hal tersebut dinyatakan dengan istilah marketing mix, marketing mix merupakan campuran (mix), yakni interaksi dari empat hal tersebut, yaitu produk (product), harga (price), promosi (promotion), dan distribusi (place). Masing-masing variabel tersebut saling berinteraksi satu sama lain guna menciptakan kepuasan konsumen dan keputusan pembelian barang atau jasa yang bermanfaat bagi konsumen.

\section{TINJAUAN PUSTAKA}

Beberapa teori yang mendasari penelitian ini diantaranya adalah : Pengertian marketing mix atau bauran pemasaran menurut Dharmmesta dan Handoko (2000 : 124) : "Marketing mix atau bauran pemasaran adalah kombinasi dari empat variabel yaitu produk, struktur harga, kegiatan promosi, dan sistem distribusi".

Fandy Tjiptono $(2005,9)$ berpendapat bahwa kepuasan pelanggan adalah sebagai berikut : "Pada hakikatnya bertujuan untuk menciptakan dan mempertahankan pelanggan. Oleh karena itu, hanya dengan memahami pelanggan maka organisasi dapat menyadari dan menghargai makna kualitas, adanya kepuasan pelanggan dapat memberikan manfaat".

Menurut Tjiptono (2006), ada 5 (lima) tahap yang dilalui konsumen dalam proses pembelian, yaitu identifikasi kebutuhan, pencarian informasi, evaluasi alternatif, keputusan pembelian, dan evaluasi purnabeli.

\section{METODE PENELITIAN}

Metode penelitian yang digunakan adalah metode deskriptif presentase, yaitu teknik skala pengukuran ordinal. Skala ordinal merupakan suatu skala yang digunakan untuk mengungkap sikap pro dan kontra, positif dan negatif, setuju dan tidak setuju terhadap suatu objek sosial (Azwar, 2001 : 97). Teknik perhitungan data dari kuesioner yang telah diisi responden dengan memberikan bobot nilai 1,2,3,4 untuk pertanyaan tertutup yang berskala ordinal.

Analisis data penelitian dilakukan menggunakan pendekatan kuantitatif, yaitu tehnik analisis data yang berkenaan dengan perhitungan untuk menjawab rumusan masalah dengan pengujian hipotesis yang dianjurkan.

Untuk menganalisis pola hubungan diantara variable, penulis menggunakan analisa jalur dengan SPSS. Analisis jalur bertujuan untuk mengetahui pengaruh langsung maupun tidak langsung seperangkat variabel bebas (eksogen) terhadap variabel terikat (endogen).

\section{HASIL DAN PEMBAHASAN}

A. Pengaruh Bauran Pemasaran dan Kepuasan Konsumen Secara Gabungan terhadap Keputusan Pembelian

Tabel 1

Koefesien Determinasi

Model Summary

\begin{tabular}{|l|c|r|r|r|}
\hline Model & \multicolumn{1}{|c|}{$\mathrm{R}$} & R Square & \multicolumn{1}{c|}{$\begin{array}{c}\text { Adjusted R } \\
\text { Square }\end{array}$} & $\begin{array}{c}\text { Std. Error of the } \\
\text { Estimate }\end{array}$ \\
\hline 1 & $.782^{\mathrm{a}}$ & .611 & .626 & 2.647 \\
\hline
\end{tabular}


Model Summary

\begin{tabular}{|l|r|r|r|c|}
\hline Model & \multicolumn{1}{|c|}{$\mathrm{R}$} & R Square & \multicolumn{1}{c|}{$\begin{array}{c}\text { Adjusted R } \\
\text { Square }\end{array}$} & $\begin{array}{c}\text { Std. Error of the } \\
\text { Estimate }\end{array}$ \\
\hline 1 & $.782^{\mathrm{a}}$ & .611 & .626 & 2.647 \\
\hline
\end{tabular}

a. Predictors: (Constant), Kepuasan Konsumen, Bauran Pemasaran

\section{Interpretasi:}

Pada tabel $1, \mathrm{R}^{2}=0,782$. Nilai koefisien korelasi sebesar 0,782 yaitu cukup mendekati +1 , maka berarti pengaruh antara bauran pemasaran dan kepuasan konsumen dengan hasil keputusan pembelian adalah memiliki pengaruh yang cukup kuat dan bersifat positif, kenaikan pada bauran pemasaran akan meningkatkan hasil keputusan pembelian dan kepuasan konsumen akan meningkatkan keputusan pembelian PT Multi Manunggal. Output ini memberikan informasi nilai koefisien determinasi $(\mathrm{KD})$ sebagai berikut :

$K D=r^{2} \times 100 \%$

$\mathrm{KD}=0,782 \times 100 \%$

$\mathrm{KD}=61,1 \%$

Koefisien Jalur

$$
\begin{aligned}
\rho_{y} \varepsilon_{1} & =\sqrt{1-R_{x y}^{2}} \\
& =\sqrt{1-0,611}=0,623
\end{aligned}
$$

Angka tersebut memiliki makna bahwa pengaruh bauran pemasaran dan kepuasan konsumen secara bersama-sama terhadap keputusan pembelian adalah $61,1 \%$. Sedangkan sisanya sebesar $38,9 \%$ dipengaruhi oleh faktor lain yang tidak diteliti atau variabel lain di luar model ini.

Untuk mengetahui apakah model regresi di atas sudah benar atau salah diperlukan uji hipotesis melalui prosedur uji F. Hasilnya adalah sebagai berikut:

Tabel 2

Uji Anova

ANOVA $^{b}$

\begin{tabular}{|ll|r|r|r|r|r|}
\hline Model & & Sum of Squares & \multicolumn{1}{|c|}{ Df } & Mean Square & F & Sig. \\
\hline 1 & Regression & 95.746 & 2 & 47.873 & 17.640 & $.000^{\mathrm{a}}$ \\
& Residual & 263.244 & 97 & 2.714 & & \\
& Total & 358.990 & 99 & & & \\
\hline
\end{tabular}

a. Predictors: (Constant), Bauran Pemasaran, Kepuasan Konsumen

b. Dependent Variabel: Keputusan Pembelian

\section{Hipotesis :}

HO : Tidak ada hubungan linier antara bauran pemasaran dan kepuasan konsumen terhadap keputusan pembelian.

Ha : Ada hubungan linier antara bauran pemasaran dan kepuasan konsumen terhadap keputusan pembelian.

Berdasarkan hasil output diketahui nilai signifikansi $0,000<0,05$, sehingga dengan demikian keputusannya adalah tolak H0 dan Ha diterima. Artinya, ada hubungan linier atau pengaruh secara gabungan antara bauran pemasaran dan kepuasan konsumen terhadap keputusan pembelian.

\section{B. Pengaruh Bauran Pemasaran dan Kepuasan Konsumen Secara Parsial terhadap Keputusan Pembelian}


Marketing mix, Customers' satisfaction

010
Untuk melihat besarnya pengaruh variabel bauran pemasaran dan kepuasan konsumen secara sendiri-sendiri atau parsial digunakan uji t, sedangkan untuk melihat besarnya pengaruh digunakan angka Beta atau Standardized Coefficients sebagai berikut :

Tabel 3

Hasil Analisis Regresi X Y terhadap Z

Coefficients $^{\mathrm{a}}$

\begin{tabular}{|c|c|c|c|c|c|c|}
\hline \multirow{2}{*}{\multicolumn{2}{|c|}{ Model }} & \multicolumn{2}{|c|}{$\begin{array}{l}\text { Unstandardized } \\
\text { Coefficients }\end{array}$} & \multirow{2}{*}{$\begin{array}{c}\text { Standardized } \\
\text { Coefficients } \\
\text { Beta }\end{array}$} & \multirow[b]{2}{*}{$\mathrm{t}$} & \multirow[b]{2}{*}{ Sig. } \\
\hline & & $\mathrm{B}$ & Std. Error & & & \\
\hline \multirow[t]{3}{*}{1} & (Constant) & 8.176 & 1.139 & & 7.181 & .000 \\
\hline & $\begin{array}{l}\text { Bauran } \\
\text { Pemasaran }\end{array}$ & .271 & .089 & .389 & 3.575 & .000 \\
\hline & $\begin{array}{l}\text { Kepuasan } \\
\text { Konsumen }\end{array}$ & .265 & .086 & .368 & 3.067 & .003 \\
\hline
\end{tabular}

a. Dependent Variabel: Keputusan Pembelian

\section{Hipotesis :}

$\mathrm{H}_{0}$ : Tidak ada hubungan linier antara bauran pemasaran dengan keputusan pembelian.

$\mathrm{H}_{1} \quad$ : Ada hubungan linier antara bauran pemasaran dengan keputusan pembelian.

Diketahui nilai Signifikansi (Sig) $0,000<0,05$, sehingga $\mathrm{H0}$ ditolak dan $\mathrm{H}_{1}$ diterima, yakni ada hubungan linier atau ada pengaruh yang nyata antara bauran pemasaran terhadap keputusan pembelian.

\section{Hipotesis :}

$\mathrm{H}_{0} \quad$ : Tidak ada hubungan linier antara kepuasan konsumen dengan keputusan pembelian.

$\mathrm{H}_{2}$ : Ada hubungan linier antara kepuasan konsumen dengan keputusan pembelian.

Diketahui nilai signifikansi (Sig) $0,003<0,05$, sehingga Ho ditolak dan $\mathrm{H}_{2}$ diterima, yakni ada hubungan linier atau ada pengaruh yang nyata antara kepuasan konsumen dengan keputusan pembelian.

\section{Pengaruh antara Bauran Pemasaran dan Kepuasan Konsumen}

Tabel 4

Pengaruh antara Bauran Pemasaran dan Kepuasan Konsumen

Model Summary

\begin{tabular}{|l|c|l|c|r|}
\hline Model & R & R Square & $\begin{array}{c}\text { Adjusted R } \\
\text { Square }\end{array}$ & $\begin{array}{c}\text { Std. Error of } \\
\text { the Estimate }\end{array}$ \\
\hline 1 & $.813^{\mathrm{a}}$ & .611 &, 834 & 2.647 \\
\hline
\end{tabular}

a. Predictors: (Constant), Bauran_Pemasaran

\section{Interpretasi:}

Pada tabel $4.33, \mathrm{R}^{2}=0,813$. Nilai koefisien korelasi sebesar 0,813 yaitu cukup mendekati +1 , maka berarti pengaruh antara bauran pemasaran dan kepuasan konsumen dengan hasil keputusan pembelian adalah memiliki pengaruh yang cukup kuat dan bersifat positif, kenaikan pada bauran pemasaran akan meningkatkan hasil kepuasan konsumen PT Multi manunggal. Output ini memberikan informasi nilai koefisien determinasi (KD) sebagai berikut :

Diketahui : 
$K D=r^{2} \times 100 \%$

$=r^{2} \quad$ koefisien korelasi

$\mathrm{KD}=0,813 \times 100 \%$

$\mathrm{KD}=66,1 \%$

Koefisien jalur :

$\begin{aligned} \rho_{y} \varepsilon_{1} & =\sqrt{1-R_{x y}^{2}} \\ & =\sqrt{1-0,661}=0,624\end{aligned}$

Angka tersebut memiliki makna bahwa pengaruh bauran pemasaran terhadap kepuasan konsumen adalah 66,1\%. Sedangkan sisanya sebesar 33,9\% dipengaruhi oleh faktor lain yang tidak diteliti atau variabel lain di luar model ini.

Tabel 5

Uji Anova

ANOVA

\begin{tabular}{|ll|r|r|r|r|l|}
\hline Model & & Sum of Squares & df & Mean Square & F & Sig. \\
\hline 1 & Regression & 92.731 & 2 & 40.812 & 19.139 & $.000^{\mathrm{a}}$ \\
& Residual & 363.032 & 97 & 2.732 & & \\
& Total & 318.390 & 99 & & & \\
\hline
\end{tabular}

a. Predictors: (Constant), Bauran_Pemasaran

b. Dependent Variable: Kepuasan_Konsumen

\section{Hipotesis:}

$\mathrm{H}_{0}$ : Tidak ada hubungan linier antara bauran pemasaran dengan kepuasan konsumen.

$\mathrm{H}_{1} \quad$ : Ada hubungan linier antara bauran pemasaran dengan kepuasan konsumen.

Diketahui nilai Signifikansi (Sig) $0,001<0,05$, sehingga $\mathrm{H}_{0}$ ditolak dan $\mathrm{H}_{1}$ diterima, yakni ada hubungan linier atau ada pengaruh yang nyata antara bauran pemasaran terhadap kepuasan konsumen.

Tabel 6

Hasil Analisis Regresi X terhadap Y

Coefficients $^{\mathrm{a}}$

\begin{tabular}{|c|c|c|c|c|c|}
\hline \multirow[t]{2}{*}{ Model } & \multicolumn{2}{|c|}{ Unstandardized Coefficients } & Standardized & \multirow[t]{2}{*}{$\mathrm{t}$} & \multirow[t]{2}{*}{ Sig. } \\
\hline & $\mathrm{B}$ & Std. Error & Beta & & \\
\hline $\begin{array}{ll} & \text { (Constant) } \\
& \text { Bauran_Pemasaran }\end{array}$ & $\begin{array}{r}124,462 \\
4,985\end{array}$ & $\begin{array}{r}14,665 \\
1,175\end{array}$ & ,338 & $\begin{array}{l}8,487 \\
4,242\end{array}$ & $\begin{array}{l}, 000 \\
, 000\end{array}$ \\
\hline
\end{tabular}

a. Dependent Variable: Kepuasan_Konsumen

\section{Hipotesis:}

$\mathrm{H}_{0}$ : Tidak ada hubungan linier antara bauran pemasaran dengan kepuasan konsumen.

$\mathrm{H}_{1} \quad$ : Ada hubungan linier antara bauran pemasaran dengan kepuasan konsumen.

Diketahui nilai Signifikansi (Sig) $0,000<0,05$, sehingga $\mathrm{H}_{0}$ ditolak dan $\mathrm{H}_{1}$ diterima, yakni ada hubungan linier atau ada pengaruh yang nyata antara bauran pemasaran terhadap kepuasan konsumen.

\section{Diagram Jalur}


Marketing mix, Customers' satisfaction

\section{2}

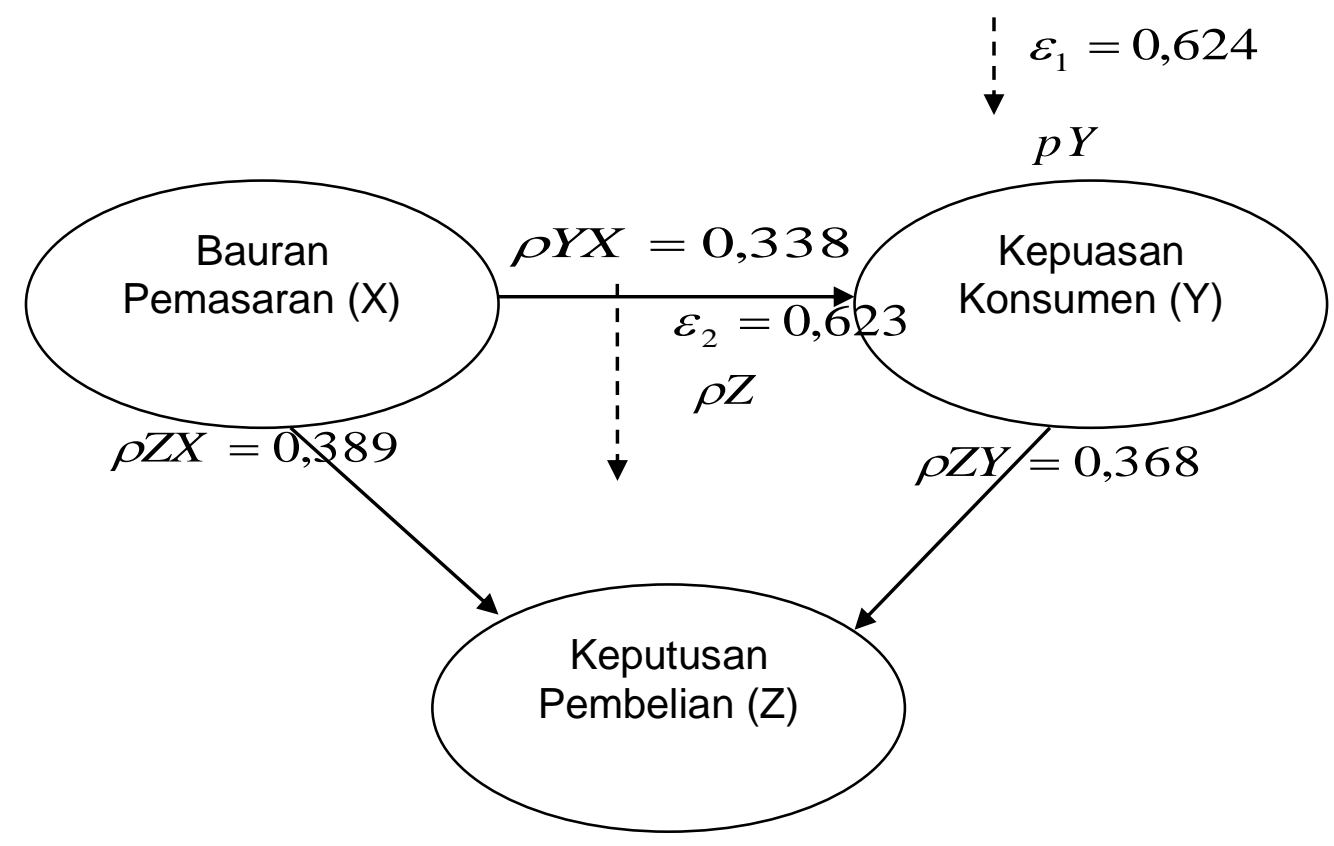

Gambar 1

Diagram Jalur

Persamaan struktural untuk diagram jalur di atas adalah sebagai berikut :

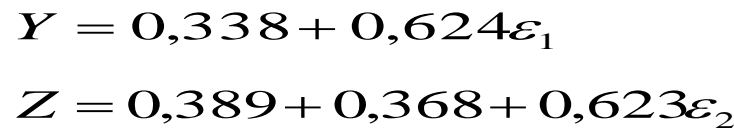

Pada persamaan regresi tersebut, variabel bauran pemasaran mempunyai pengaruh yang positif dan signifikan terhadap variabel kepuasan konsumen sebesar 0,338, variabel bauran pemasaran berpengaruh positif dan signifikan terhadap variabel keputusan pembelian sebesar 0,389, dan variabel kepuasan konsumen mempunyai pengaruh yang positif dan signifikan terhadap variabel keputusan pembelian sebesar 0,368, artinya apabila variabel bauran pemasaran dan variabel kepuasan konsumen naik, maka variabel keputusan pembelian juga meningkat dan jika variabel bauran pemasaran dan variabel kepuasan konsumen turun, maka variabel keputusan pembelian juga menurun.

\section{E. Pembahasan}

Berdasarkan hasil perhitungan di atas, maka dapat dibuat analisis atau pembahasan terhadap hipotesis penelitian :

\section{Hipotesis 1 :}

Bauran pemasaran mempunyai pengaruh yang positif dan signifikan terhadap kepuasan konsumen. Berdasarkan tabel 6 diperoleh tabel standardized coefficients beta X (Bauran Pemasaran) terhadap Y (Kepuasan Konsumen) sebesar 0,338. Bahwa antara variabel bauran pemasaran dan kepuasan konsumen memiliki pengaruh yang kuat, karena diperoleh nilai sebesar 0,338 menandakan pengaruh kedua variabel tersebut kuat.

\section{Hipotesis 2 :}

Bauran pemasaran mempunyai pengaruh yang positif dan signifikan terhadap keputusan pembelian. Berdasarkan tabel 3 diperoleh tabel standardized coefficients beta X (Bauran Pemasaran) terhadap Z (Keputusan Pembelian) sebesar 0,389. Bahwa antara variabel bauran pemasaran dan keputusan pembelian memiliki pengaruh yang kuat, karena diperoleh nilai sebesar 0,389 menandakan pengaruh kedua variabel tersebut kuat. 
Kepuasan konsumen mempunyai pengaruh yang positif dan signifikan terhadap keputusan pembelian. Berdasarkan tabel 3 diperoleh tabel standardized coefficients beta $\mathrm{Y}$ (Kepuasan Konsumen) terhadap Z (Keputusan Pembelian) sebesar 0,368. Bahwa antara variabel kepuasan konsumen dan keputusan pembelian memiliki pengaruh yang kuat, karena diperoleh nilai sebesar 0,368 menandakan pengaruh kedua variabel tersebut kuat.

Koefisien Korelasi :

Pengaruh bauran pemasaran dan kepuasan konsumen secara gabungan terhadap keputusan pembelian adalah nilai koefisien korelasi sebesar 0,782 yaitu cukup mendekati +1 , maka berarti pengaruh antara bauran pemasaran dan kepuasan konsumen dengan hasil keputusan pembelian adalah memiliki pengaruh yang positif dan signifikan, kenaikan pada bauran pemasaran akan meningkatkan hasil keputusan pembelian dan kenaikan pada kepuasan konsumen akan meningkatkan hasil keputusan pembelian PT Multi manunggal.

Sedangkan koefisien determinasi senilai 0,611 bahwa pengaruh bauran pemasaran dan kepuasan konsumen secara bersama-sama terhadap keputusan pembelian adalah $61,1 \%$. Sedangkan sisanya sebesar $38,9 \%$ dipengaruhi oleh faktor lain yang tidak diteliti atau variabel lain di luar model ini. Pada koefisien jalur senilai 0,623 menandakan kategori pengaruh variabel bauran pemasaran dan variabel kepuasan konsumen secara gabungan terhadap variabel keputusan pembelian memiliki pengaruh yang kuat.

Pengaruh antara bauran pemasaran dan kepuasan konsumen dengan nilai koefisien korelasi sebesar 0,813 yaitu cukup mendekati +1 , maka berarti pengaruh antara bauran pemasaran dan kepuasan konsumen dengan hasil keputusan pembelian adalah memiliki pengaruh yang bersifat positif dan signifikan, kenaikan pada bauran pemasaran akan meningkatkan hasil kepuasan konsumen PT Multi manunggal. Sedangkan koefisien determinasi senilai 0,661 bahwa pengaruh bauran pemasaran dan kepuasan konsumen secara bersama-sama terhadap keputusan pembelian adalah $66,1 \%$. Sedangkan sisanya sebesar $33,9 \%$ dipengaruhi oleh faktor lain yang tidak diteliti atau variabel lain di luar model ini. Pada koefisien jalur senilai 0,624 menandakan kategori pengaruh variabel bauran pemasaran dan variabel kepuasan konsumen secara gabungan terhadap keputusan pembelian.

\section{SIMPULAN}

Hasil penelitian mengenai analisis bauran pemasaran dalam kaitannya dengan kepuasan konsumen dan pengaruhnya terhadap keputusan pembelian produk furniture PT Multi Manunggal dapat dibuat beberapa simpulan sebagai berikut :

1. Bauran pemasaran mempunyai pengaruh yang positif dan signifikan terhadap kepuasan konsumen. Antara variabel bauran pemasaran dan variabel kepuasan konsumen memiliki pengaruh yang kuat.

2. Bauran pemasaran mempunyai pengaruh yang positif dan signifikan terhadap keputusan pembelian. Antara variabel bauran pemasaran dan variabel keputusan pembelian memiliki pengaruh yang kuat.

3. Kepuasan konsumen mempunyai pengaruh yang positif dan signifikan terhadap keputusan pembelian. Antara variabel kepuasan konsumen dan variabel keputusan pembelian memiliki pengaruh yang kuat.

\section{DAFTAR PUSTAKA}

A, Usmara. 2003. Strategi Beru Manajemen Pemasaran. Amara Books : Jakarta. Buchari, Alma. 2005. Manajemen Pemasaran dan Pemasaran Jasa. Penerbit Alfabeta. Bandung.
Marketing mix, Customers' satisfaction 
Marketing mix, Customers' satisfaction

$\underline{014}$
Dharmmesta, B. S. dan Handoko, H, 2000. Manajemen Pemasaran: Analisis Perilaku Konsumen. Yogyakarta: PBFE Universitas Gajah Mada.

Gerson. Richard F. 2002. Mengukur Kepuasan Pengguna. Cetakan Kedua. Jakarta: PPM.

Haryadi Sarjono dan Winda Julianita. 2011. SPSS vs Lisrel. Salemba Empat. Jakarta. Kotler, Philip. 2000. Manajemen Pemasaran di Indonesia: Analisis, Perencanaan, Implementasi dan Pengendalian, Jakarta: Salemba Empat.

_ _ _ _ 2000. Manajemen Pemasaran Edisi Millenium 2. Terjemahan Hendra Teguh dkk. Jakarta: Prenhallindo.

_ _ _ _ _ 2004. Marketing In Venus. Penerbit PT Gramedia Pustaka Utama.

Kotler dan Armstrong, (terjemahan Alexander Sindoro). 2001. Dasar-Dasar Pemasaran. Prenhallindo. Jakarta.

_ _ _ _ _ 2001. Prinsip-Prinsip Pemasaran Jilid I \& II. Jakarta: Erlangga.

Mowen dan Minor. 2002. Perilaku Konsumen. Jilid 2, Edisi Kelima, Alih Bahasa, Dwi Kartini Yahya, Editor: Nurcahyo Maharani, Jakarta: Erlangga.

Nergiyantoro, Burhan. 2004. Statistik Terapan untuk Penelitian Ilmu-Ilmu Sosial. (Edisi Ketiga). Yogyakarta: Gadja Mada University.

Nugroho, Adi. 2002. Perilaku Konsumen. Penerbit Studia Press.

Peter, J. P., Olson. J. C., (2004). Perilaku konsumen dan strategi pemasaran, Edisi keempat (terjemahan). Jakarta: Erlangga.

Rangkuti, Freddy. 2003. Measuring Customer Satisfaction: Teknik Mengukur dan Strategi Meningkatkan Kepuasan Pelanggan, Penerbit Gramedia Pustaka Utama.

Sarwono, Jonathan. 2007. Analisis Jalur untuk Riset Bisnis dengan SPSS, Yogyakarta: Andi Offset.

Schiffman, Leon G. And Leslie L. Kanuk. 2000. Consumer Behaviour,Fifth Edition, Prentice-Hall Inc., New Jersey.

Setiadi, Nugroho J., 2003. Perilaku Konsumen. Edisi Pertama, Cetakan Pertama, Penerbit Prenada Media, Jakarta.

Simamora, Bilson 2001. Memenangkan Pasar Dengan Pemasaran Efektif dan Profitabel, Penerbit Gramedia Pustaka Utama, Jakarta.

Sutisna. 2001. Perilaku Konsumen dan Komunikasi Pemasaran. Bandung: PT Remaja Rosdakarya.

Swasta, Basu. 2001. Azas-azas Marketing. Edisi 3. Yogyakarta: Liberty.

Swasta, Basu dan Handoko, Hani, T. 2000. Manajemen Pemasaran Analisa dan Perilaku Konsumen. Yogyakarta: Liberty.

Tjiptono, Fandy. 2001. Strategi Pemasaran. Edisi Pertama, Penerbit Andi Ofset, Yogyakarta.

Fitri, Komalasari. 2010. Pengaruh Bauran Pemasaran Terhadap Keputusan Pembelian Produk Handphone Nokia E Series. Universitas Gunadarma. Tidak Dipublikasikan.

Putri, Anggreni. 2011. Pengaruh Penerapan Bauran Pemasaran Terhadap Tingkat Kepuasan Konsumen Dalam Jasa Pelayanan Di RSU Surya Husadha. Universitas Mahendradatta Denpasar. Tidak Dipublikasikan. 